\title{
Antifungal effect of the cumulative application of biostimulant and fertilizers on young cocoa fruits rot at Tafissou site, Centre-East of Côte d'Ivoire
}

\author{
Franck Zokou ORO ${ }^{1 *}$, Hermann-Desiré LALLIE ${ }^{2}$, Souleymane SILUE ${ }^{2}$, \\ Kouakou Manassé N'DRI and Hortense Atta DIALLO ${ }^{3}$ \\ ${ }^{I}$ Department of de Plant biology, Faculty of Biological Sciences, Peleforo GON COULIBALY University. BP \\ 1328 Korhogo. \\ ${ }^{2}$ Department of Genetics-Biochemistry, Faculty of Biological Sciences, Peleforo GON COULIBALY \\ University. BP 1328 Korhogo. \\ ${ }^{3}$ Phytopathology Research Unit, Department of Plant and Environmental Protection, Nangui Abrogoua \\ University. 02 BP 801 Abidjan 02. \\ *Corresponding author; E-mail: franckoro@yahoo.fr
}

Received: $28-10-2020$

Accepted: $27-12-2020$

Published: $31-12-2020$

\begin{abstract}
The use of biostimulants as an alternative way to chemical, often toxic, remains one of the best approaches to control cocoa black pod disease caused by Phytophthora spp. This study has been carried out to evaluate the effect of biostimulant's applications number and the cumulative action in case of applying previously fertilizers. The experimental design consisted of a Fischer block with six treatments (T01, T02, T1, T2, T3 and T4) and repeated three times. This design was replicated on two sites, one with previous fertilizer (DAE) and the other without previous fertilizer (DSE). Observations were made monthly on each test tree. The biostimulant Banzai was applied for 3 or 4 consecutive months depending on the treatment at each site. The data collected included the total number of cherelles produced and the number of rotten cherelles. From these, data were deduced the rates of healthy cherelles on which the Kruskal-Wallis test was applied to compare treatments between them and between sites. The results showed that four applications of the biostimulant with fertilizer provided better control than three applications without fertilizer. The results also showed that the majority of treatments at the DAE site were more effective than treatments at the DSE site. In conclusion, four applications Banzai coupled with fertilizer have achieved the best rates of healthy cherelles whatever the site. Regarding the cumulative effect of the previous fertilizer with Banzai, treatments of the site with the previous fertilizer were still better than the treatment site without fertilizer.
\end{abstract}

(C) 2020 International Formulae Group. All rights reserved.

Keywords: Cocoa, Antifungal effect, black pod disease, Banzai Biostimulant, Côte d'Ivoire.

\section{INTRODUCTION}

Cocoa tree is a perennial crop native from tropical rainforests of Central America (Janny et al., 2003). It belongs to the family of
Malvaceae, and the genus of Theobroma (Motamayor et al., 2002). Cocoa is a strategic product for Côte d'Ivoire economy as it accounts for $30 \%$ of export earnings and $15 \%$ 
of the gross domestic product (CCC, 2015). Much of this production comes from small farms and is the unique source of income for some 5.5 million farming families (Koua, 2018). However, cocoa farming in Côte d'Ivoire is facing to several difficulties due to pests and diseases (N'guessan, 2016) including black pod disease and cocoa swollen shoot disease (Kouakou et al., 2011). Black pod disease is a fungal disease caused by Phytophthora spp, of which two species (Phytophthora palmivora and Phytophthora megakarya) are well known in Côte d'Ivoire cocoa growing areas (Akrofi, 2015; Coulibaly, 2015). These two fungical species cause rotting of cherelles and pods and cause significant yield losses (Kébé et al., 2009).

In Côte d'Ivoire, production losses due to this disease vary from 20 to $45 \%$, or even $60 \%$ in some regions if no phytosanitary protection is provided (CNRA, 2017). In the view of this situation, each year a range of fungicides is used to control black pod in cocoa trees. These products, although often effective, are most of the time very expensive and poorly applied by producers (Mahob et al., 2014). This has as consequence in recrudescence of the disease and the impoverishment of the soil, hence the use of alternative products including biostimulants. Biostimulants are products that stimulate plant vitality (Oro et al., 2019). These biostimulants sometimes play the role of biocontrol and stimulators of natural defences depending on their composition (Faessel et al., 2014). According to some studies, the algae extracts contained in biostimulants give plants a strong resistance to cold and drought (Mooney and Van Staden, 1985). These algal extracts thus give plants increased resistance to fungal diseases, insect attacks and nematode infestation of roots (Wu et al., 1997). A biostimulant based on algal extracts is capable of controlling pathogens. Indeed, bacterial biostimulants enhance the defensive capacities of plants against diseases (Van Loon et al., 1998). The advantage of biostimulants is that they are less expensive, environmentally friendly and less hazardous to health (Faessel et al., 2016). The biostimulant Banzai is a product that improves the growth and yield of cherelles and pods (Oro et al., 2019). It stimulates the vigour of cherelles and pods against diseases and external stresses (Callivoire, 2016). However, there is less information about the role of biostimulants in resistance to biotic stresses (Desfontaines et al., 2018). In recent years a few experiments have attempted to demonstrate this (Faessel et al., 2016; Yakhin, 2017). It is in this context that this study was being carried out to evaluate the antifungal effect of the biostimulant Banzai and fertilizer on the rot of cherelles. Specifics objectives are to:

- Evaluate the effect of the number of biostimulant Banzai applications according to the different doses on the control of cherelles rot.

- Evaluate the cumulative effect of the previous fertilizer and the different doses of Banzai on the control of cherelles rot.

\section{MATERIALS AND METHODS}

\section{Study Area}

The study took place in the locality of Tafissou (Figure 1), located in the department of Djekanou (6॰48'61.4 "N 5०11110.6 "W) in central-eastern Côte d'Ivoire. The climate in this zone is classified into four seasons: a dry season which is between November and February, a large rainy season which starts in March and ends in July with rainfall of about $1,200 \mathrm{~mm}$ per year, a small dry season from August to September and a small rainy season from September to October. The climate is also characterized by a relative humidity of $80 \%$ (Yao, 2007).

\section{Experimental design and treatments}

The experimental design consists of a completely randomized Fischer block with six treatments (T01, T02, T1, T2, T3 and T4) repeated three times (Figure 3). Each treatment contains twenty (20) cocoa trees. T01 is the control without Banzai application but with fertilizer, T02 is the control without Banzai application and without fertilizer, T1 is a plot consisting of three applications of Banzai with fertilizer, T2 is four applications of Banzai without fertilizer, $\mathrm{T} 3$ is three applications of 
Banzai without fertilizer and $\mathrm{T} 4$ is four applications of Banzai with fertilizer (Table 1).

In the study area, the experimental design was installed on two sites: one site with previous non-fertilizer application (DSE) and another site with previous fertilizer application (DAE). The Fertilizer Precedent Site (DAE) was a farm that had received fertilizer during the last three years prior to the trial set-up. The No Previous Fertilizer (DSE) system is a field that has not been fertilized in the last three years.

\section{Trials experimentation on sites}

Setting up the test consisted of a prospective survey that identified appropriate experimental sites and plots for study. The test plots were selected taking into account their cultural background and the age of the test plants. The systems set up on each of the experimental sites consisted of blocks of approximately $1800 \mathrm{~m}^{2}$ each, i.e. $300 \mathrm{~m}^{2}$ for each elementary plot. The experimental blocks were delimited using a decameter and the boundaries were marked by posts. In each elementary plot, the selected trees were numbered from 1 to 20 . The identification and marking of the test cocoa trees were followed by a sanitary harvest by removing all already rotten chérelles (Figure 2).

\section{Application of Banzai biostimulant and SUPERCAO fertilizer}

Banzai was applied to the basic plots or treatments (T1, T2, T3 and T4) at both sites using a sprayer. It was applied for three or four consecutive months depending on the type of treatment. The different doses of each treatment were deduced from the initial dose $(800 \mathrm{ml} / \mathrm{ha}$ ), i.e. $144 \mathrm{ml}$ of Banzai diluted in 16 $\mathrm{L}$ of water. SUPERCAO fertilizer was applied twice (July and August) during the study in the T01, T1 and T4 elementary plots. The fertilizer was applied at a dose of $150 \mathrm{~g}$ per tree within a radius of $30 \mathrm{~cm}$ around each test tree.

\section{Data collection}

Observations were made following each test tree up to $2.5 \mathrm{~m}$ above the ground. The data collection covered two parameters including the total number of cherelles produced and the total number of rotten cherelles. A cherelle is a cocoa young fruit which size is less than $6 \mathrm{~cm}$. Each counted cherelle was tied with a string at the stalk to facilitate the counting of new cherelles produced by the test cocoa tree. The observation of the cherelles was carried out every month for nine months (June to March). From these data, the rate of healthy cherelles was deduced.

\section{Statistical analysis of the data.}

The statistical analysis focused on the rate of healthy cherelles, which represents the rate of control of black pod disease. The healthy cherelles rate is the proportion of healthy cherelles to cherelles produced (Equation 1). The descriptive analysis consisted in representing the dynamics of the healthy cherelles rate by treatment and by observation period for the two sites using the Excel 2013 spreadsheet.

Equation 1: $\quad \mathrm{HCR}=\frac{\mathrm{TNCP}-\mathrm{NRC}}{T N C P}$

HCR: Healthy cherelles Rate

NRC: Number of rotten cherelles

TNCP: Total number of cherelles produced.

Inferential analysis was used to compare the average rates of healthy cherelles per treatment. Thus, the boxplots were first performed to compare the distribution of the rate of healthy cherelles per treatment. Then, the Kruskal-Wallis statistical test was applied to evaluate the observed differences between the treatments and the control and between the treatments themselves. This test was also used to compare treatments within and between sites. Finally, a classification was performed to prioritize the treatments according to their effectiveness. 


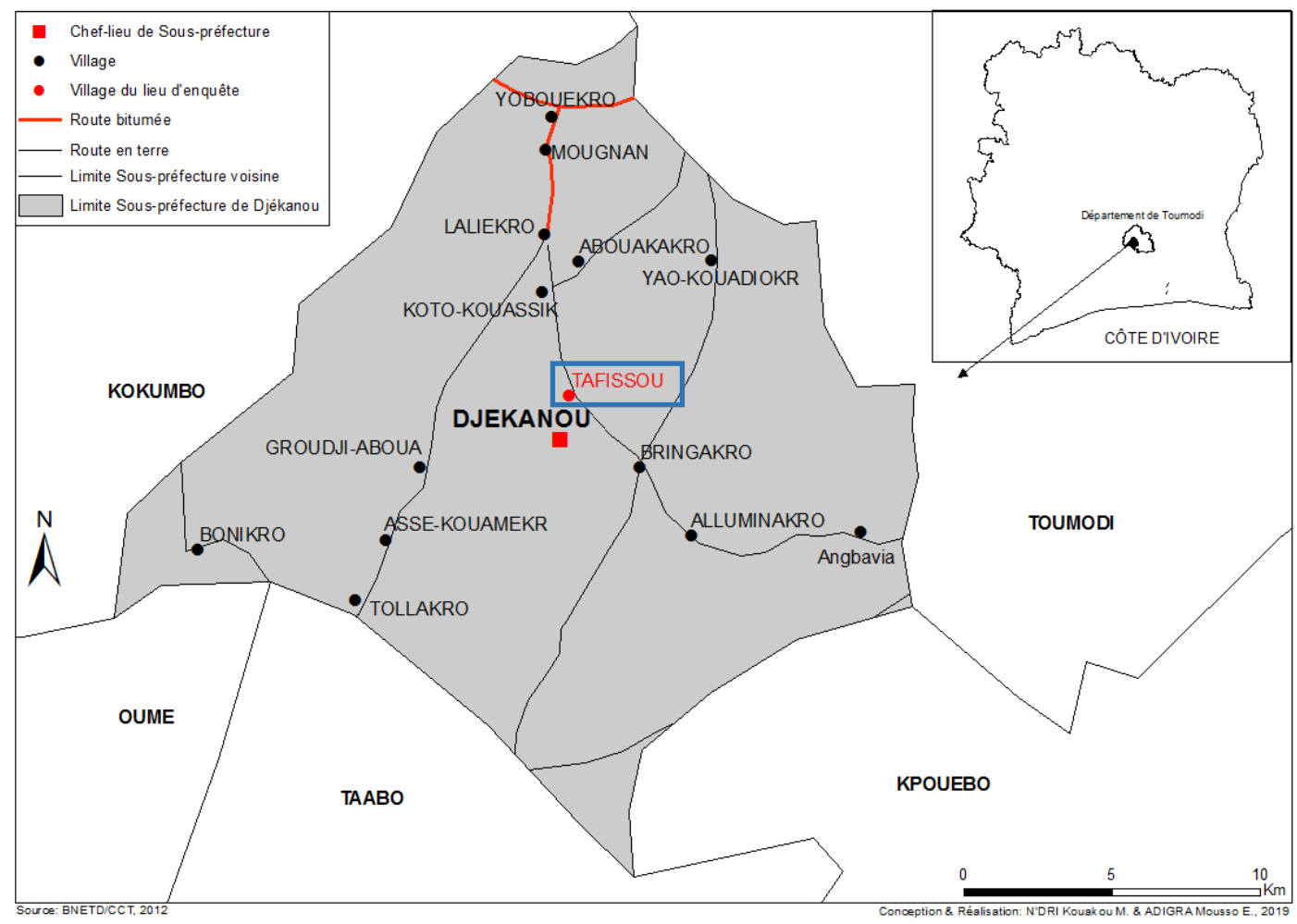

Figure 1 : Map of the study area showing the site of Tafissou.

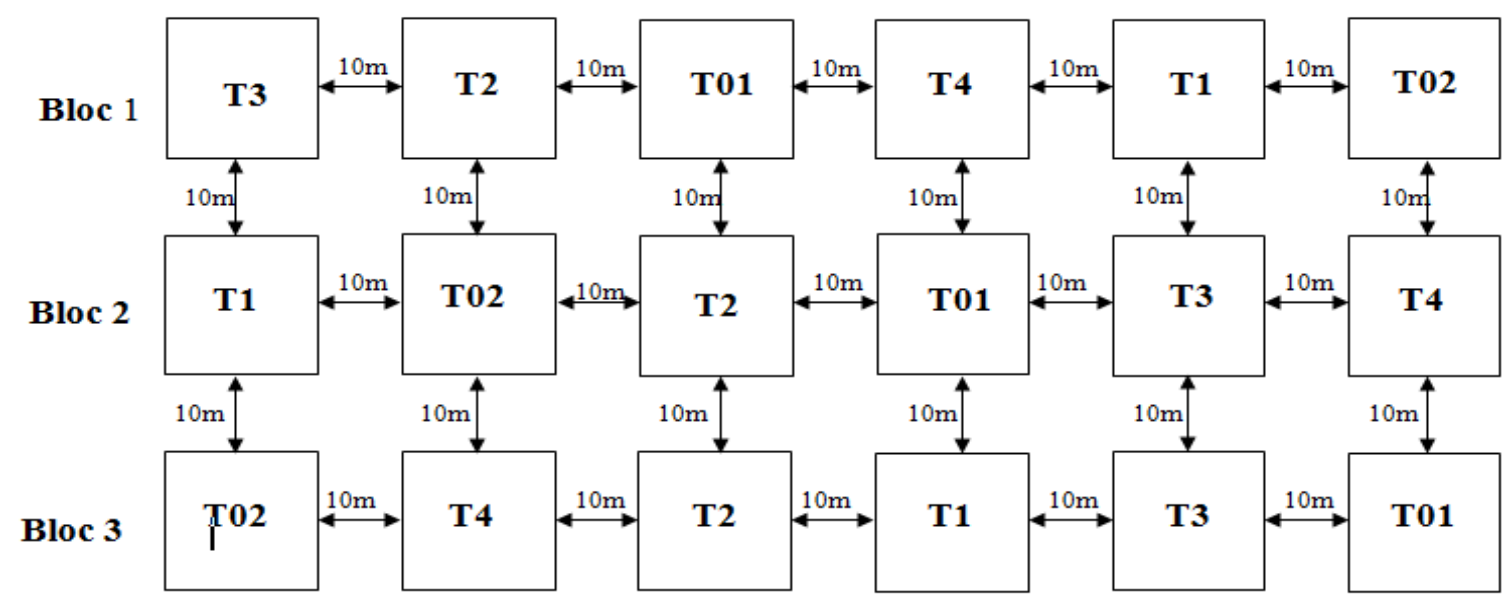

Figure 3: Diagram of the experimental set-up.

T01: Control without application of Banzai with fertilizer

T02: Control without application of Banzai without fertilizer

T1: 3 applications of Banzai with fertilizer

T2: 4 applications of Banzai without fertilizer

T3: 3 applications of Banzai without fertilizer

T4: 4 applications of Banzai with fertilizer 
Table 1: Number of applications of SUPERCAO and Banzai.

\begin{tabular}{ccc}
\hline Treatments & SUPERCAO & Banzaï \\
\hline T01 & ++ & - \\
\hline T02 & - & - \\
\hline T1 & ++ & +++ \\
\hline T2 & - & ++++ \\
T3 & - & +++ \\
\hline T4 & ++ & ++++ \\
\hline
\end{tabular}

Fertilizer: (+) one application, (-) no application

Banzai: (+) one application, (-) no application

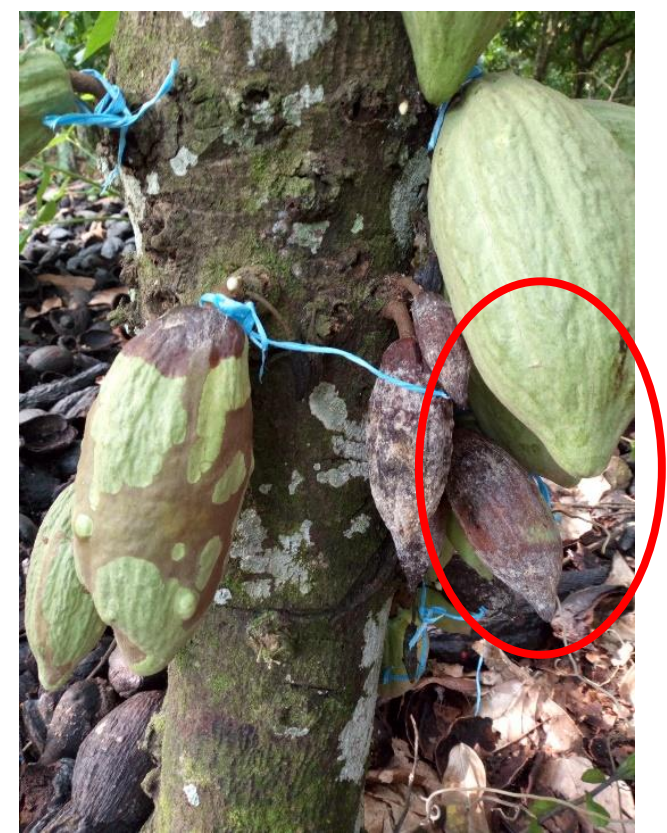

Figure 2: Symptoms of cherelles rot and black pods in a peasant farm (Photo taken by Koffi Alain).

\section{RESULTS}

Effect of Banzai and the SUPERCAO fertilizer on the control of cherelles rot for the site with previous fertilizer (DAE)

The result of the data description showed overall that plots treated with Banzai had a better control rate than control plots with an average rate of healthy cherelles of $79 \%$ against $46 \%$ for T01 and 52\% for T02 (Table 2).

The evolution of the healthy cherelles rate per treatment shows that the $\mathrm{T} 4$ treatment has the best healthy cherelles rate than the other treatments with $89 \%$ (Figure 4).
The boxplots

Rate of healthy cherelles around $89 \%$, followed by group B composed of T3 and T2 with healthy representing the healthy cherelles rate as a function of treatment showed two trends. A first trend that groups the treated plots with the highest healthy cherelles rates around a minimum median of $70 \%$, and a second trend relative to the control plots with median healthy cherelles rates of nearly $50 \%$ (Figure $5)$.

The result of the Kruskal-Wallis test applied on the healthy heart rate showed that there is a significant difference $(\mathrm{p}=0.000<0.05)$ between the treated and control plots on the one 
hand and between the treated plots themselves on the other hand. This difference is confirmed by the classification of the treatments into five groups (A, B, C, D and E). Group $\mathrm{A}$ is represented by treatment $\mathrm{T} 4$ with the highest cherelles rates of $77 \%$ and $79 \%$ respectively. Group $\mathrm{C}$ is represented by treatment $\mathrm{T} 1$ with a healthy cherelles rate of $70 \%$ followed by controls T02 and T01 which belong respectively to group $\mathrm{D}$ and $\mathrm{E}$ with healthy cherelles rates of $52 \%$ and $46 \%$ respectively (Table 3). The existence of a significant difference between the treated plots and the control plots shows that the biostimulant Banzai was effective in controlling the cherelles rot. The fact that T2 (4 applications of Banzai without fertilizer) and T3 (3 applications of Banzai without fertilizer) belong to the same group shows that there is no difference between three applications and four applications of Banzai without fertilizer. In the case of fertilizer application during the experiment, four applications of Banzai give a better rate of healthy cherelles than three applications of Banzai. Therefore, the statistical difference observed in the T01 and T02 controls shows that the fertilizer applied (SUPERCAO) during the experiment did not have a positive effect on the control of cherelles rot. In fact, the control T02, which did not receive the SUPERCAO fertilizer, had a higher rate of healthy cherelles $(52 \%)$ than the control T01 which received the fertilizer.

\section{Effect of Banzai and SUPERCAO fertilizer on the control of rotting cherelles for the unprecedented fertilizer site (DSE)}

The results of the data description showed in overall that the plots treated with Banzai had a better rate of healthy cherelles than the control plots with an average rate of healthy cherelles equivalent to $77 \%$ against $29 \%$ for $\mathrm{T} 01$ and $37 \%$ for $\mathrm{T} 02$ whatever the observation period (Table 4). Comparison of the treatments between them using the dynamics of the evolution of the healthy cherelles rate shows that treatment $\mathrm{T} 4$ (87\%) had a higher rate of healthy cherelles than the other treatments T1, T2 and T3 which had on average healthy cherelles rate of $74 \%$ (Figure 6).

Boxplots of healthy cherelles rate versus plots allowed the identification of three trends according to median dispositions. Thus, the controls T01 and T02 form a first trend with a median rate of healthy cherelles around $40 \%$, the second trend contains $\mathrm{T} 1$ and $\mathrm{T} 2$ with a median rate of healthy cherelles around $75 \%$ and the third trend contains $\mathrm{T} 3$ and $\mathrm{T} 4$ with median rates of healthy cherelles close to $90 \%$ (Figure 7).

The Kruskal-Wallis test applied on the healthy cherelles rate showed a significant difference between the treated and the controlled plots. The classification of the treatments revealed that there are four groups (A, B, BC and C). Treatments T4 and T3 had the highest rate of healthy cherelles and form group A with average rates of $87 \%$ and $82 \%$ respectively. The lowest rate was observed in the $\mathrm{T} 01$ control represented by group $\mathrm{C}$ with an average rate of $30 \%$. The intermediate average rates are represented by groups $\mathrm{B}$ and $\mathrm{BC}$. Group B corresponded to treatments T2 and T1 with mean rates of $75 \%$ and $67 \%$ respectively. The BC group corresponded to the T02 control with a rate of $37 \%$ (Table 5). The statistical difference observed between the treated plots and the control showed that the Banzai biostimulant had a positive effect on the control of cherelles rot. The statistical difference observed between T4 (4 applications of Banzai with fertilizer) and T1 (3 applications of Banzai with fertilizer) showed that four applications of Banzai with fertilizer was more effective than the three applications with fertilizer. On the other hand, the significant difference observed between T2 (4 applications of Banzaï without fertilizer) and T3 (3 applications of Banzaï without fertilizer) shows that in the case of no fertilizer application, three applications of Banzaï is better than four applications. In addition, the fact that the plots treated with fertilizer and the plots without fertilizer treatment belong to the same group shows that the SUPERCAO fertilizer applied during the experiment had no expected effect on the control of cherelles rot. 


\section{Cumulative effect of previous fertilizer and Banzai on the control of cherelles rot}

Figure 8 shows the comparison of the rates of healthy cherelles at the two sites per treatment. Descriptive analysis shows that the site with previous fertilizer recorded the highest healthy cherelles rates with the exception of the T3 treatment.

The boxplots of healthy cherelles rates from the two sites allowed the treatments to be grouped into five trends based on medians. The first trend includes T01 and T02 of the DSE site with a lower healthy cherelles rate of approximately $40 \%$, followed by the second trend which groups T01 and T02 of the DAE site with a healthy cherelles rate of approximately 50\%. The third trend includes T1 treatment of both sites with a rate of about $75 \%$, followed by the fourth trend with a rate of about $80 \%$ represented by $\mathrm{T} 2$ of the DAE site, T3 of the DAE site and T2 of the DSE site. Finally, the fifth trend is represented by $\mathrm{T} 4$ of the DAE group, T3 of the DAE site, and T4 of the DSE group with an average rate of healthy cherelles close to 90\% (Figure 9). The KruskalWallis test applied to the healthy cherelles rates of the two sites indicated that there was a significant difference between the treated plots of the two sites. The classification resulting from this test showed eight distinct groups of treatments according to their effectiveness.

Thus, group A is represented by the T4 DAE treatment, T4 DSE treatment and T3 DSE treatment with rates of $90 \%, 87 \%$ and $82 \%$ respectively. Group $A B$ is represented only by T2 DAE treatment with a rate of healthy cherelles close to 79\%. The T3 DAE, T2 DSE, and T1 DAE treatments belong to group B with respective rates of $77 \%, 75 \%$ and $71 \%$. The $\mathrm{BC}$ group is represented only by T1 DSE with a healthy cherelles rate of $67 \%$. The T02 treatment of the DAE site belongs to group C and has a rate of $52 \%$ of healthy cherelles. T01 DAE treatment, T02 DSE treatment and T01 DSE treatment belong to groups DC, D, and E respectively with respective rates of $47 \%, 37 \%$ and $30 \%$ (Table 6).

Comparison of the treatments across sites shows that overall the DAE site treatments had a better rate of healthy cherelles than the DSE site treatments (Table 7). This shows that the previous fertilizer had a positive effect in controlling the cherelles rot.

Table 2: Global rate of healthy cherelles per treatment for the site with previous fertilizer.

\begin{tabular}{cccc}
\hline Treatments & $\begin{array}{c}\text { Number of } \\
\text { produced } \\
\text { cherelles }\end{array}$ & $\begin{array}{c}\text { Number of } \\
\text { rotten } \\
\text { cherelles }\end{array}$ & $\begin{array}{c}\text { Global rate of } \\
\text { healthy } \\
\text { cherelles }\end{array}$ \\
\hline T01 & 1716 & 924 & $46,15 \%$ \\
\hline T02 & 1615 & 772 & $52,20 \%$ \\
\hline T1 & 4110 & 1203 & $70,73 \%$ \\
\hline T2 & 2539 & 529 & $79,17 \%$ \\
\hline T3 & 2775 & 632 & $77,23 \%$ \\
\hline T4 & 3977 & 430 & $89,19 \%$ \\
\hline
\end{tabular}




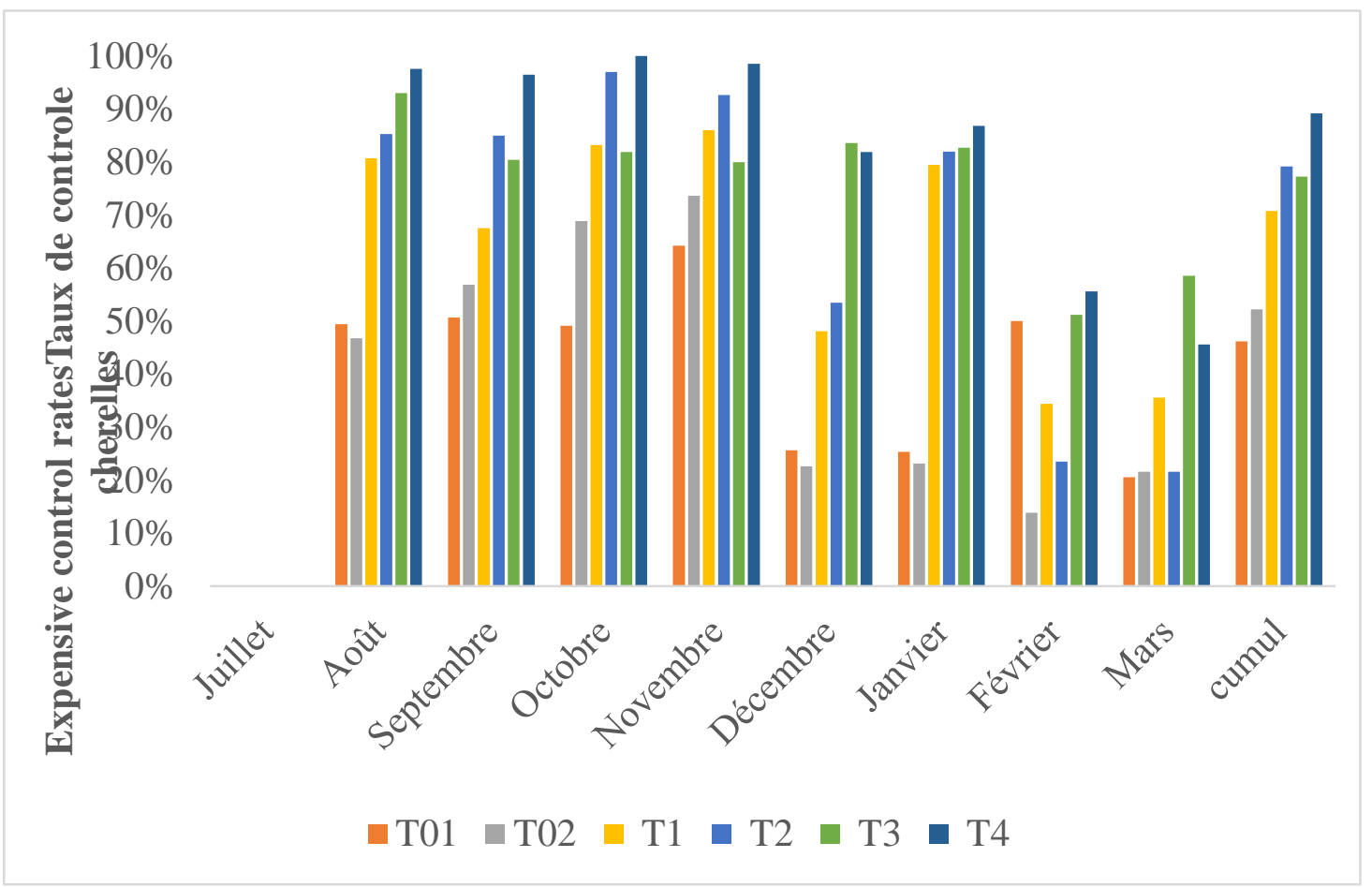

Figure 4 : Control rate of cherelles rot by observation and treatment for the site with previous fertilizer (DAE).

\section{Test de Kruskal-Wallis à échantillons indépendants}

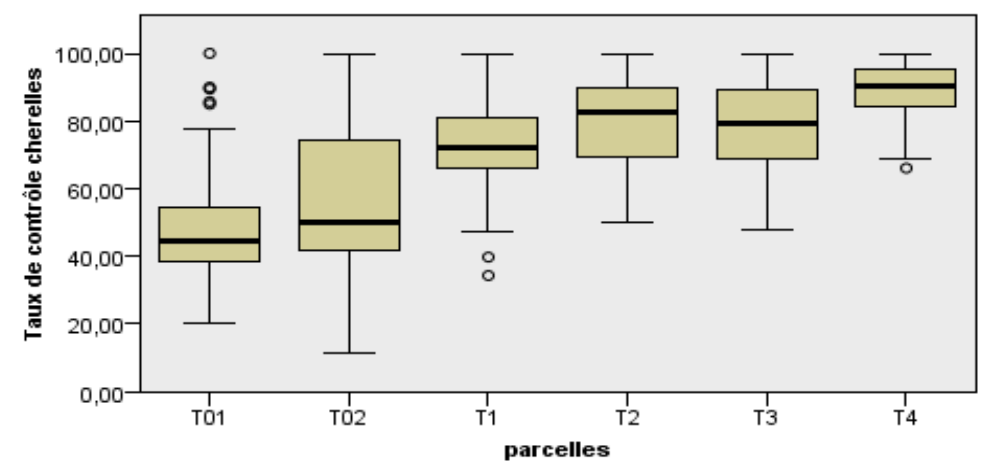

\begin{tabular}{|lr|}
\hline N Total & 360 \\
\hline Statistique de test & 156,150 \\
\hline Degrés de liberté & 5 \\
\hline Sig. asymptotique (test bilatéral) &, 000 \\
\hline
\end{tabular}

Figure 5 : Moustache box showing median of treatments as a function of the control rate of cherelles rot. 
Tableau 3 : Classification showing the average rate of control of cherelles rot by treatment.

\begin{tabular}{ccc}
\hline Treatments & Average rate & Groups \\
\hline T4 & $89,19 \%$ & A \\
\hline T2 & $79,17 \%$ & B \\
T3 & $77,23 \%$ & B \\
T1 & $70,73 \%$ & $\mathbf{C}$ \\
T02 & $52,20 \%$ & D \\
T01 & $46,15 \%$ & E \\
\hline
\end{tabular}

Tableau 4 : Global rate of healthy cherelles per treatment for the unprecedented fertilizer site.

\begin{tabular}{cccc}
\hline Treatments & $\begin{array}{c}\text { Number of } \\
\text { produced cherelles }\end{array}$ & $\begin{array}{c}\text { Cumulation of } \\
\text { rotten cherelles }\end{array}$ & $\begin{array}{c}\text { Global control } \\
\text { rate of cherelles }\end{array}$ \\
\hline T01 & 710 & 498 & $\mathbf{2 9 , 8 6 \%}$ \\
T02 & 701 & 441 & $\mathbf{3 7 , 0 9 \%}$ \\
T1 & 1429 & 474 & $\mathbf{6 6 , 8 3 \%}$ \\
T2 & 937 & 234 & $\mathbf{7 5 , 0 3 \%}$ \\
T3 & 1000 & 183 & $\mathbf{8 1 , 7 0 \%}$ \\
T4 & 1035 & 131 & $\mathbf{8 7 , 3 4 \%}$ \\
\hline
\end{tabular}

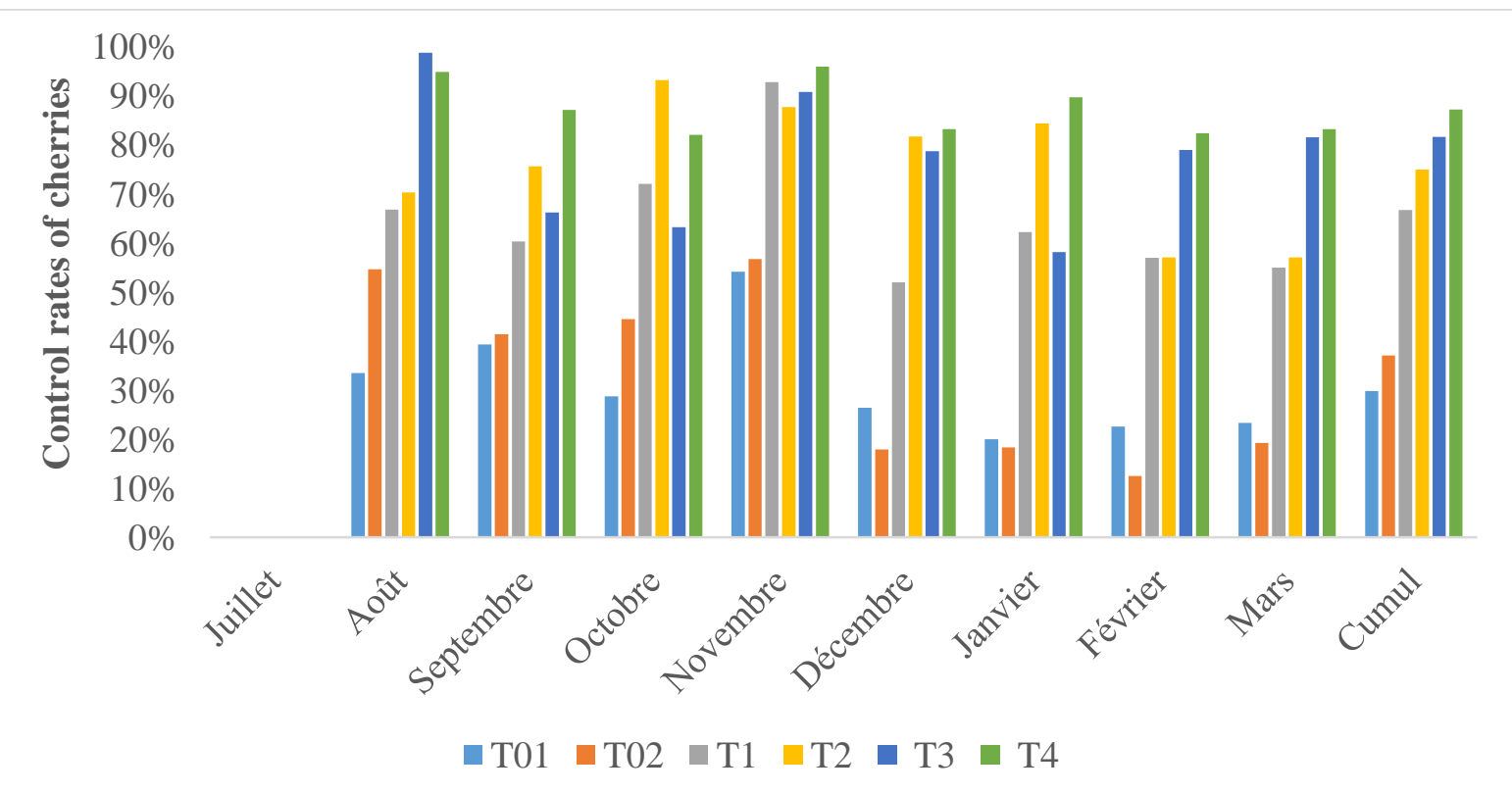

Figure 6 : Control rate of cherelles rot by observation and by treatment for the No Previous Fertilizer Site (DSE). 


\section{Test de Kruskal-Wallis à échantillons indépendants}

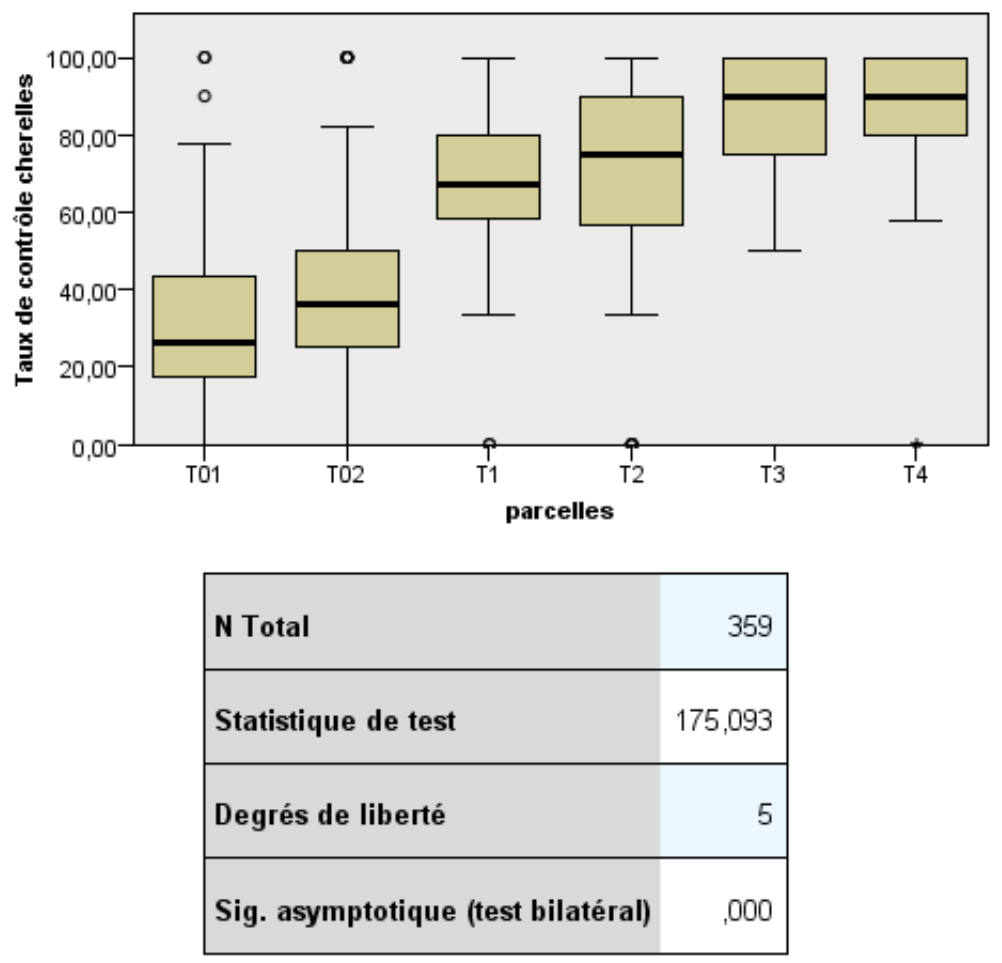

1. La statistique de test est réglée pour les ex aequo.

Figure 7: Boxplots showing median of treatments as a function of the control rate of cherelles for the unprecedented fertilizer design (DSE).

Table 5 : Showing the average row of the control rate of cherelles rot per treatment for the unprecedented fertilizer device (DSE).

\begin{tabular}{|c|c|c|}
\hline Traitements & Taux Moyens & Group \\
\hline $\mathrm{T} 4$ & $87,34 \%$ & $\mathbf{A}$ \\
\hline T3 & $81,70 \%$ & $\mathbf{A}$ \\
\hline $\mathrm{T} 2$ & $75,03 \%$ & B \\
\hline $\mathrm{T} 1$ & $66,83 \%$ & B \\
\hline T02 & $37,09 \%$ & BC \\
\hline T01 & $29,86 \%$ & $\mathbf{C}$ \\
\hline
\end{tabular}


Table 6 : Classification of average rate healthy cherelles by Site (DAE and DSE) and by treatment.

\begin{tabular}{ccc|}
\hline Sites and plots & Average rate & Groups \\
\hline DAET4 & $89,19 \%$ & A \\
\hline DSET4 & $87,34 \%$ & A \\
DSET3 & $81,70 \%$ & A \\
DAET2 & $79,17 \%$ & AB \\
DAET3 & $77,23 \%$ & B \\
DSET2 & $75,03 \%$ & B \\
DAET1 & $70,73 \%$ & B \\
DSET1 & $66,83 \%$ & BC \\
DAET02 & $52,20 \%$ & C \\
DAET01 & $46,5 \%$ & DC \\
DSET02 & $37,09 \%$ & D \\
DSET01 & $29,86 \%$ & E \\
\hline
\end{tabular}

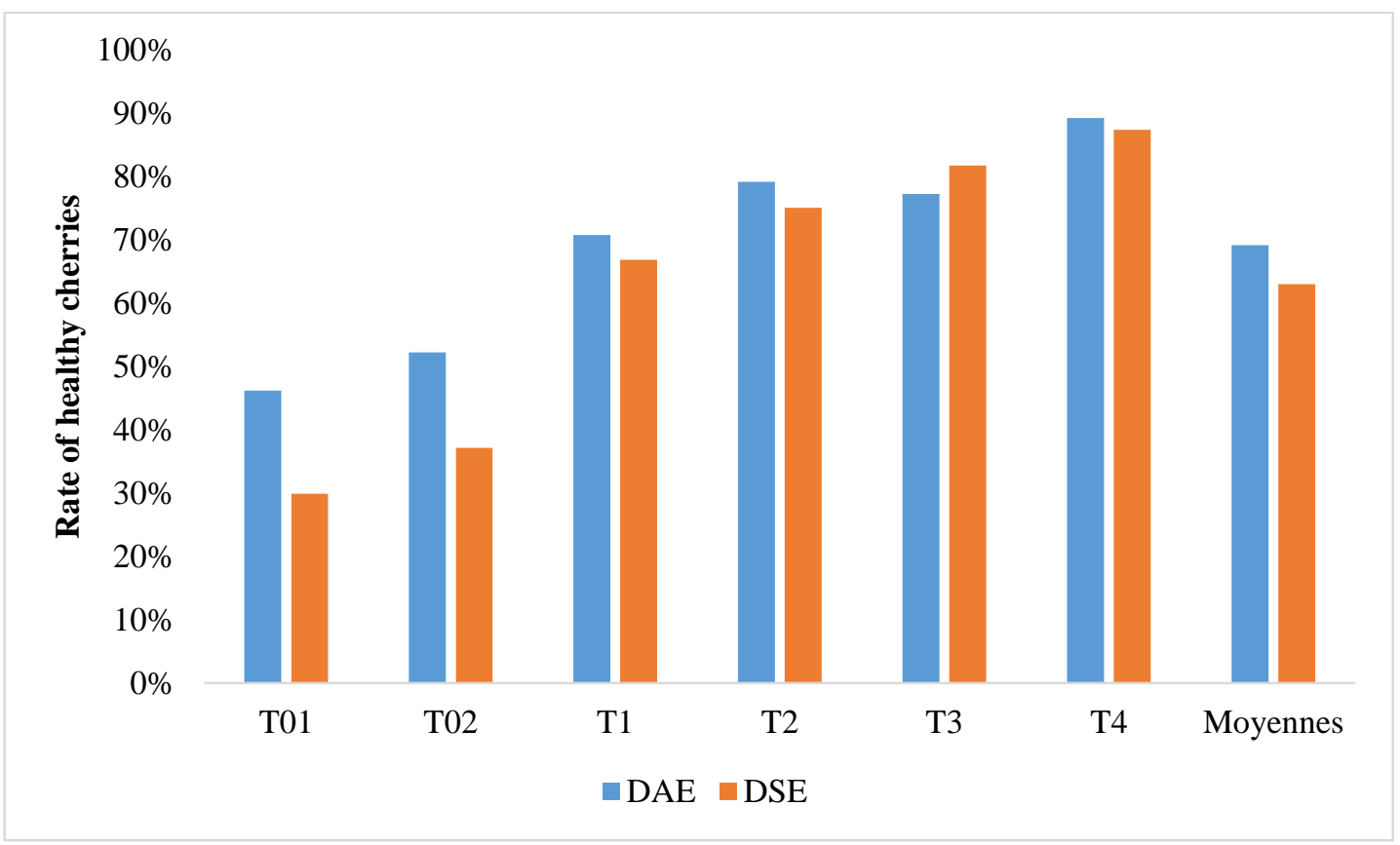

Figure 8 : Histogram of the rate of healthy cherelles by treatment and by site. 


\section{Test de Kruskal-Wallis à échantillons indépendants}

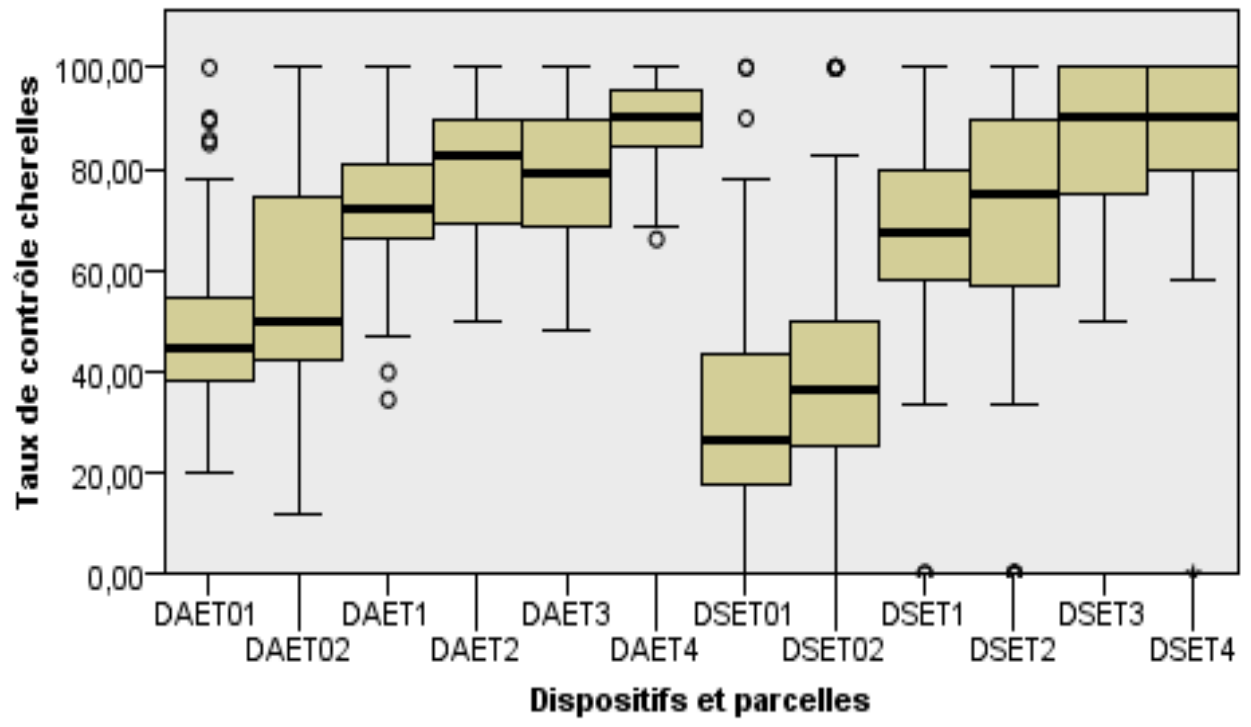

Figure 9 : Boxplots of healthy cherelles rates by site (DAE and DSE) and by treatment.

Table 7 : Comparison of the two sites (DAE and DSE) according to the rate of healthy cherelles per treatment.

\begin{tabular}{clllllll}
\hline $\begin{array}{c}\text { Device and } \\
\text { plots }\end{array}$ & T01 & T02 & T1 & T2 & T3 & T4 & Averages \\
\hline DAE & $46,15 \%$ & $52,20 \%$ & $70,73 \%$ & $79,17 \%$ & $77,23 \%$ & $89,19 \%$ & $\mathbf{6 9 , 1 1 \%}$ \\
\hline DSE & $29,86 \%$ & $37,09 \%$ & $66,83 \%$ & $75,03 \%$ & $81,70 \%$ & $87,34 \%$ & $\mathbf{6 2 , 9 8 \%}$ \\
\hline
\end{tabular}

\section{DISCUSSION}

At the previous fertilizer site (DAE) and at the site without previous fertilizer (DSE), statistical results showed that the biostimulant Banzai was effective in the control of cherelles rot with reference to the control plots. Indeed, the control plots $\mathrm{T} 01$ and $\mathrm{T} 02$, which had not received Banzai biostimulant application, were subjected to high parasitic pressure, particularly due to fungical pathogen (Muller, 1974). This is elucidated by the high rates of healthy cherelles in the treated plots and the low rates of healthy cherelles in the control plots.
The statistical test also showed that four applications of Banzai coupled with fertilizer were more effective than the three applications with or without fertilizer at any site (DAE and DSE). This result is in line with the recommendations indicated in the Banzai biostimulant data sheet (Callivoire, 2016).

On both sites, fertilizer applied alone during the experiment had no effect in limiting the decay of cherelles. In the case of the site with previous fertilizer (DAE), the control plot that did not receive fertilizer had a higher rate of healthy cherelles than the control plot that received fertilizer. For the No Previous Fertilizer Site, the unfertilized control plot had 
a statistically identical rate of healthy cherelles as the fertilized control plot. Indeed, fertilizer stimulates the production of cherelles only, unlike biostimulant, which is capable of stimulating both the production of cherelles and the natural defense systems against pathogens (Oro et al., 2020). This is in line with the studies conducted by Fardeau and Jonis (2004), which state that the effect of the biostimulant can create a cell barrier that promotes resistance to the penetration of pathogens into the plant. These results are also in line with those of Lakhdar (2018), who showed that biostimulants trigger defence processes at the plant level through the elicitors they contain.

Concerning the cumulative effect of the biostimulant Banzai and the previous fertilizer, the results obtained show that the treatments of the site with previous fertilizer (DAE) mostly had higher rates of healthy cherelles than the treatments of the site with previous without fertilizer. This result is in line with the results of the report of the Coffee-Cocoa Council (2015) which showed that the effect of the fertilizer is visible provided that it is applied at least twice during two successive years.

\section{Conclusion}

At the end of this study, it appears that the biostimulant Banzaï was effective both on the site with previous fertilizer and on the site without previous fertilizer in the control of the cherelles rot in reference to the control plots. Specifically, at the site with previous fertilizer (DAE), the T4 treatment (4 applications of Banzai with fertilizer) had the best rate of healthy cherelles. At the site without previous fertilizer (DSE), the T3 (3 applications of Banzai without fertilizer) and T4 (4 applications of Banzai with fertilizer) treatments better controlled the cherelles rot. In general, the four applications of Banzai coupled with fertilizer allowed to obtain the best rates of healthy cherelles whatever the site. Concerning the cumulative effect of the previous fertilizer with Banzai, the treatments of the site with previous fertilizer were always better than the treatments of the site without previous fertilizer.

\section{COMPETING INTERESTS}

The authors declare that they have no competing interests.

\section{AUTHORS' CONTRIBUTIONS}

FZO managed the literature research, designed the study, wrote the protocol, participated in data collection and performed the statistical analysis, and wrote article. HDL managed the analyses of study, and wrote article. SS designed the study and approved final protocol. KMN participated in data collection, data analysis and wrote the first draft of the manuscript. HAD was the principal investigator.

\section{ACKNOWLEDGMENTS}

Our thanks go to the firm SAG SARL for facilitating the implementation of the study, the collection of data and the production of the final report of the study.

\section{REFERENCES}

Akrofi AY. 2015. Phytophthora megakarya: Review on its status as a pathogen on cacao in West Africa. African Crop Science Journal, 23(1) : 67-87.

Association Rurale Agricole de Guyane (ARAG). 2017. Theobroma cacao L. groupe génétique "Guiana" Développement de la filière locale du Cacao guyanais Programme d'actions de l'association ARAG. 28p.

Callivoire. 2016. Callivoire. Fiche technique du biostimulant Banzaï. 2p.

Conseil Café Cacao (CCC). 2015. Manuel du planteur de cacao.90 p.

Coulibaly K, Kébé B, Koffi K, Mpika J, Koné D. 2013. Caractérisation des isolats de Phytophthora spp du verger cacaoyer de Cote d'Ivoire. Journal of Applied Biosciences 70: 5567-5579. DOI: $10.4314 /$ jab.v70i1.98757

Centre National de Recherche Agronomique (CNRA). 2017. Bien lutter contre la pourriture brune des cabosses du cacaoyer en Côte d'Ivoire, $4 \mathrm{p}$.

Desfontaines 1, Rotin P et Ozier-lafontaine H. 2018. Les Biostimulants : Qu'en savonsnous ? Quelles alternatives pour 
l'agriculture Guyanaise ? Innovations Agronomiques. $\quad$ 64: 31-46. https://www6.inrae.fr/ciag/content/downl oad/6361/46613/file/Vol64-4-

Desfontaines.pdf

Fardeau JC, Jonis M. 2004. Phytostimulants et éliciteurs pour végétaux : propriétés et garanties réglementaires. Alter. Agri., 65: 21-24.

http://itab.asso.fr/downloads/AlterAgri/A A65.pdf

Faessel L, Gomy C, Nassr N, Tostivint C, Hipper C, Dechanteloup A. 2014. Produits de stimulation en agriculture visant à améliorer les fonctionnalités biologiques des sols et des plantes [archive]. Étude des connaissances disponibles et recommandations stratégiques. Rapport d'étude, (2014) 148 pages.

Faessel L, Tostivint C. 2016. Les produits de stimulation en agriculture : un état des connaissances. Notes et études socioéconomiques.37p.

Janny GM, Vos BJ, Ritchie et Julie F. 2003. Guide pour la formation des facilitateurs. CABI Biosciences, 114p.

Kébé BI, Joseph M, Kouamé FN, Prakash KH, Gary SS, Aké S. 2009. Isolement et identification de microorganismes indigènes de cacaoyères en Côte d'Ivoire et mise en évidence de leurs effets antagonistes vis-àvis de Phytophthora palmivora, agent de la pourriture brune des cabosses. Sciences \& Nature, 6(1): 71-82.

Website:

C:/Users/herma/Downloads/48581-

Article\%20Text-63282-

11020091203\%20(1).pdf

Koua S. 2018. Caractérisation vergers et des maladies de cacao de la Côte d'Ivoire : cas des départements d'Abengourou, Divo et Soubré. Journal of Animal \& Plant Sciences, 35(3): 5706-5714. http://m.elewa.org/Journals/wpcontent/uploads/2018/03/2.Koua_-1.pdf

Kouakou K, Kebe BI, Kouassi N, Anno AP, Ake S, Muller E. 2011. Impact de la maladie virale du swollen shoot du cacaoyer sur la production de cacao en milieu paysan à Bazré (Côte d'Ivoire); Journal of Applied Biosciences; 43 : 2947-2957.

http://agritrop.cirad.fr/563759/1/docume nt_563759.pdf

Lakhdar F. 2018. Contribution à l'étude des potentialités antiproliférative et antibactérienne des algues brunes et rouge de la côte d'El Jadida pour une valorisation médicale et environnementale. Thèse de Doctorat de l'Université de Nantes, soutenu à El Jadida (Maroc). Biologie des organismes-Biotechnologie animale, végétale et microbienne. $238 \mathrm{p}$.

Ministère de l'Agriculture, Pêcheries et Alimentation du Québec. 2014. Les Biostimulants : Parlons-en. Rapport 2014: MAPAQ Ste-Martine. 60p.

Mooney PA, Van staden J. 1985. Effect of seaweed concentrate on the growth of wheat under conditions of water stress. South. Afric. J. Sci., 81: 632-633.

Motamayor J C, Risterucci AM, Lopez PA, Ortiz CF, Moreno A, Lanaud C. 2002. Cacao domestication I : the origin of the cacao cultivated by the Mayas. Heredity, 89: $\quad 380-386, \quad 153$ p. $\quad$ DOI: 10.1038/sj.hdy.6800156.

Muller RA. 1974. Effect of prophylactic mesures on the dissemination of Phytophthora palmivora. Phytophthora Disease of Cocoa, Gregory PH (ed). Longman: London; 169-178.

N'guessan AH, N'guessan KM, Kouamé NN, Kouassi KP, N'guessan WP. 2016. Distribution géographique et importance des foreurs de tige dans le verger de cacaoyers de Côte d'Ivoire. Journal of Animals and Plant Sciences, 27 (3): 42824292.

https://www.m.elewa.org/JAPS/2016/27. 3/3.nguessan.pdf

Oro FZ, Lallié HD, Doumbouya M, Koigny J, Diallo HA. 2019. Influence du niveau d'entretien des parcelles de cacaoyers sur la prévalence de la pourriture brune des cabosses à Kipiri, Sud-Ouest de la Côte d'Ivoire. Journal of Applied Biosciences ; 
144:

14813-14821.

DOI:

https://doi.org/10.35759/JABs.144.10

Oro FZ, Lallié HD, Brou GK, Bi-Zaouli P, Fofana JI, Diallo HA. 2020. Efficacité du Biostimulant Banzaï TM sur l'amélioration de la couverture foliaire des cacaoyers apparemment sains et des cacaoyers atteints de la maladie du "Swollen shoot" à Petit Bondoukou, SudOuest de la Côte d'Ivoire. Journal of Applied Biosciences; 146: 15064-15073. DOI: https://doi.org/10.35759/JABs.v146.9

Van Loon LC, Bakker PAHM and Pieterse CMJ. 1998. Systemic resistance reduced by rhizosphere bacteria. Annual Review of Phytopathology, 36(1): 453-483. DOI: https://doi.org/10.1146/annurev.phyto.36 .1 .453

Wu Y, Jenkins T, Blunden G, Whapman C, Hankins SD. 1997. The role of betaines in alkaline extracts of Ascophyllum nodosum in the reduction of Meloidogyne javanica and $M$. incognita infestations of tomato plants. Fundam. Appl. Nematol. 20: $99-102$.

https://horizon.documentation.ird.fr/exldoc/pleins_textes/fan/010009429.pdf

Yakhin OI, Lubyanov AA, Yakhin IA, Brown PH. 2017. Biostimulants in Plant Science: A global Perspective. Frontiers in Plant Science, 7 : 1-32. DOI : https://doi.org/10.3389/fpls.2016.02049

Yao KA. 2007. Caractéristiques physiques des sols brunifiés dérivés des formations du complexe volcano-sédimentaire de Kanhankro (Toumodi) en moyenne Côte d'Ivoire. Rev. CAMES - Série A, 05 : 11p.

Mahob RJ, Ndoumbè-Nkeng M, Ten Hoopen GM, Dibog L, Nyassé S, Rutherford M, Mbenoun M, Babin R, Amang A Mbang J, Yede, Bilong Bilong CF. 2014. Pesticides use in cocoa sector in Cameroon: characterization of supply source, nature of actives ingredients, fashion and reasons for their utilization. Int. J. Biol. Chem. Sci., 8(5): 1976-1989. DOI: 10.4314/ijbcs.v8i5.3 